\title{
Analisa Mikro Hunian Bernuansa Islam
}

\author{
Ghoustanjiwani Adi Putra \\ Dosen Prodi Arsitektur, Fak. Teknik Sipil dan Perencanaan, ITN Malang \\ e-mail: ghoustanputra@lecturer.itn.ac.id \\ Budi Fathoni \\ Dosen Prodi Arsitektur, Fak. Teknik Sipil dan Perencanaan, ITN Malang \\ e-mail: budi@lecturer.itn.ac.id
}

\begin{abstract}
ABSTRAK
Penelitian ini merupakan penelitian multih tahun yang akan dilakukan selama 3 tahun (2021-2023) dimana masing masing tahun akan di batasi berdasarkan zona pembahasan yaitu: Analisa mikro (2021), Analisa Messo (2022) dan Analisa Makro (2023). Analisa Diskriptif ini merupakan hasil dari penelitian tahun pertama (2021) yang bertujuan memberikan gambaran dan wawasan konsep hunian islami yang dianalisa secara mikro (Hunian). Studi kasus yang dipilih di dalam penelitian ini yaitu Perumahan PRIMALAND: dePRIMA yang merupakan perumahan Islami di kota Malang. Hunian Islami akan dikaji dalam berberapa variabel kajian antara lain: Bentuk, Fungsi dan Tatanan Spasial ruang dalam nya. Dalam penelitian tahun ini peneliti berfokus pada analisa mikro hunian islami yaitu pada bentuk, ruang dalam/tatanan Spasial, dan fungsi hunian berdasarkan kajian arsitektur islami. Dari hasil Analisa diskriptf ini didapat bahwa secara mikro (hunian) pada perumahan Primaland dapat di simpulkan secara tipologi bentuk sudah memenuhi Prinsip Elemen bentuk dalam Arsitektur islam, namun secara fungsi Spasial Arsitektur Islam masih memerlukan penerapan yang lebih detail.
\end{abstract}

\section{Kata kunci : Arsitektur Islam, Analisa Mikro, Hunian}

\section{ABSTRACT}

This research is a multi-year research that will be conducted for 3 years (2021-2023) where each year will be limited based on the discussion zone, namely: Micro Analysis (2021), Messo Analysis (2022) and Macro Analysis (2023). This descriptive analysis is the result of the first year of research (2021) which aims to provide an overview and insight into the microanalyzed concept of Islamic housing (Hunian). The case study selected in this study is the PRIMALAND Housing: dePRIMA which is an Islamic housing estate in the city of Malang. Islamic housing will be studied in several study variables, including: Form, Function and Spatial Arrangement of its internal

PAWON: Jurnal Arsitektur, Nomor 01 Volume VI, Januari - Juni Tahun 2022, ISSN 2597-7636 
space. In this year's research, the researchers focused on micro-analysis of Islamic housing, namely the form, interior space/spatial arrangement, and residential function based on the study of Islamic architecture. From the results of this descriptive analysis, it was found that from a micro (residential) perspective in Primaland housing, it can be concluded that the typology of the form has met the Principles of Elements of Form in Islamic Architecture, but the Spatial function of Islamic Architecture still requires a more detailed application.

\section{Kata kunci : Islamic Architecture, Micro Housing, Housing}

\section{PENDAHULUAN}

Pada tahun 2020 tercatat kurang lebih jumlah penduduk sebesar 1.749.780 jiwa, sedangkan di tahun 2015 sebesar 1.732.236 jiwa. Dari kedua data per 5 tahun tersebut dapat menunjukkan adanya pertambahan sekitar 17.544 jiwa per 2 tahun nya, atau 7.250 jiwa per tahun nya. Hal ini merupakan salah satu bukti melesatnya jumlah pertambahan penduduk di kota malang tiap tahunnya selama kurun waktu per 5 tahun. Oelhkarena itu kepadatan penduduk di Kota Malang dapat dikatakan sangat padat.

Luas Kota Malang sendiri hanya 110,06 km2 dan berada di tengahtengah Kabupaten Malang. Dengan adanya tingkat kepadatan dan jumlah penduduk yang makin bertambah tiap tahunya, tentunya akan berpengaruh terhadap perkembangan fisik kawasan berupa infrastruktur Kawasan yang terbangun. Selain itu dengan adanya pertambahan jumlah penduduk yang pesat ini tentunya fasilitas yang dapat menunjang mereka, diantaranya adalah kebutuhan akan perumahan dan kawasan permukiman (Supriyanto, 2015).

Pesatnya kebutuhan perumahan dan permukiman dikota malang dapat dilihat dari berkembang pesatnya properti di Malang Raya. Hal ini juga tak lepas dari pemberesan dan pembangunan infrastruktur, bagus dalam kota, ataupun dari dan menuju Malang. Selain itu Pemerintahan Kota Malang, Kota Batu dan Kabupaten Malang akan berkolaborasi untuk mengoptimalkan infrastruktur Bersama. Berbagai Developer perumahan dan pemukiman tumbuh kembang dan pesat dengan adanya minat dan kebutuhan perumahan yang tinggi ini. Istilah Perumahan Islami pun demikian menjamur sebagai salah satu strategi marketing pengembang dalam mempasarkan produk properti yang dikembangkan. 


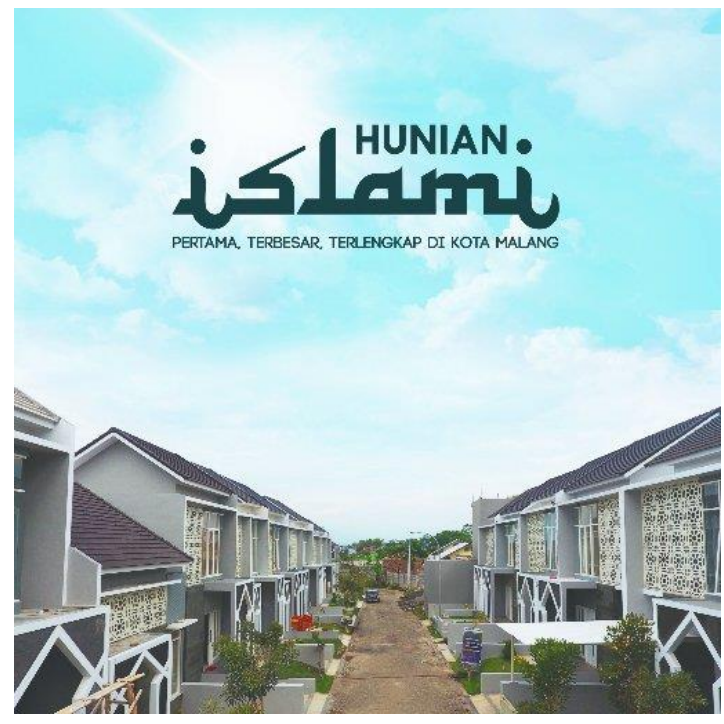

PRIMALAND dePRIMA merupakan salah satu perumahan Islami di kota Malang. Perumahan ini mengembangkan produk cluster dengan tema Hunian Minimalis berkonsep islami dengan nama De Prima Tunggulwulung. Kompleks hunian oleh pengembang dePRIMA LAND ini merupakan Hunian Islami bernuansa eksklusif modern yang dipadukan dengan nilai islami. Perumahan ini berlokasi cukup strategis di pusat kota Malang. Perumahan ini di dukung dengan lingkungan yang baik, bersih serta mendukung penuh dalam kegiatan berdakwah, sistem keamanan yang 24 jam, ditunjang dengan berbagai fasilitas seperti taman komunal, gate satu arah Cluster ini berada Jl. Loncat Indah No.a2, Tunggulwulung, Kec. Lowokwaru, Kota Malang. Perumahan berkonsep islami ini dinilai cocok untuk penghuni yang menginginkan hunian dengan akses yang mudah dijangkau, dengan konsep dan sistem manajemen perumahan yang islami dan sesuai syariat islam

\section{TINJAUAN PUSTAKA}

\section{Analisa Mikro Arsitektur}

Tipologi Ruang, Tipologi ruang adalah analisa ruang yang terkait dengan perencanaan tata ruang, dimana adanya karakteristik ruang dan elemen ruang yang memiliki hubungan antara satu sama lain. Hubungan termasuk topologi dan geometri, dan membedakan perencanaan tata ruang dari klasik masalah penugasan linier. Hubungan membuat proses desain menjadi rumit dan sulit dengan meningkatkan biaya komputasi. Rencana optimal ditentukan oleh interaksi dan biaya perjalanan antar elemen ruang dalam

PAWON: Jurnal Arsitektur, Nomor 01 Volume VI, Januari - Juni Tahun 2022, ISSN 2597-7636 
denah. Ini menyiratkan bahwa elemen ruang yang saling berkaitan erat akan cenderung terletak berdekatan satu sama lain pada denah.

Pesan dalam Arsitektur Islam. Dalam (GHASEMZADEH, 2013) Arsitektur islam dikenal luas karena desainnya yang unik dan kreatif. Arsitek Islam mematok kreativitas mereka untuk membangkitkan keyakinan melewati batin dan spriritual mereka melalui penggunaan bentuk abstrak yang menghasilkan karya seni yang megah dan indah. Arsitektur islam semakin berkembang dengan gaya arsitektur yang menjadi alternatif desain yang adaptif dengan landasan memenggunakan seni Islam. Landasan seni islam ini mampu menciptakan karya yang unik baik dari artis-artis atau seniman islam mapun arsitek muslim. Tujuan utama karya seni yang berlandaskan islam ini adalah untuk menyampaikan pesan-pesan lewat batin dan spiritual Islam dan bukan untuk menawarkan kepuasan estetis bagi mata semata saja.

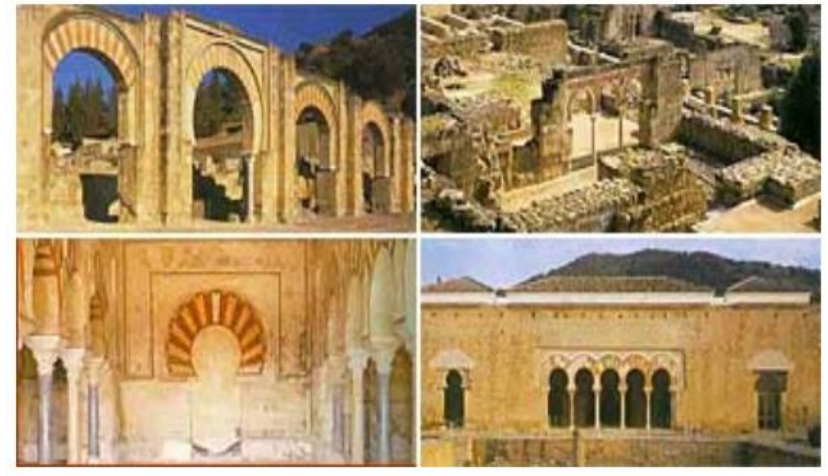

Gambar 1 Arsitektur Islam menyampaikan pesan

(Sumber:GHASEMZADEH, 2013)

Pada perkembangan nya Arsitektur Islam berkembang dengan waktu yang membawa diversifikasi dalam desain. Kota-kota Islam di timur-tengah adalah cerminan persatuan yang adaptif terhadap kondisi setempat, yang digambarkan melalui rangkaian penataan bangunan seperti masjid, keraton, madrasah/sekolah, dan wisma (Arnold, 1931) Simbol dan tanda yang digunakan dalam bangunan Islam tidak selalu membawa pesan atau makna agama. Beberapa formulir tidak jelas dan tidak spesifik dalam arti. Satusatunya desain yang berisi pesan yang mudah dipahami adalah kaligrafi. Simbol yang digunakan dalam desain arsitektur adalah ekspresi dari keyakinan budaya atau agama. Bangunan mengalami perbaikan dan pemugaran konstan yang tergantung pada tren yang ada. Artinya terkadang simbol yang digunakan hanya untuk tujuan estetika. 
Dekoratif Sebagai Pesan, dalam (Hattstein, 20013) Bangunan-bangunan Islami sangat didekorasi dengan berbagai warna. Meskipun desain termasuk dekorasi untuk bagian internal dan eksternal dari struktur, sebagian besar dekorasi disediakan untuk bagian interior. Dalam kebanyakan kasus, satusatunya bagian yang dihias pada eksterior adalah pintu masuk dan kubah.

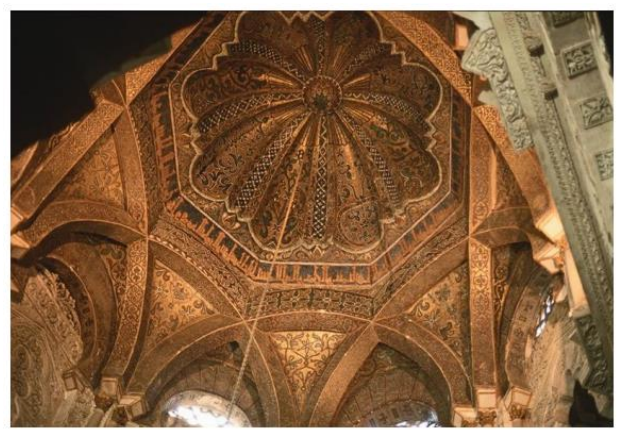

Gambar 2 Pesan yang disampaikan dalam Dekoratif Arsitektur Islam (Sumber:GHASEMZADEH, 2013)

Gambar 2 menunjukkan interior yang didekorasi dari kubah. Teknik dekoratif yang paling umum termasuk kaligrafi, geometri, hewan gambar, dan desain bunga. Desain geometris banyak digunakan untuk struktur keagamaan untuk menggambarkan berbagai simbol Islam.

Arsitektur Islam banyak menggunakan lengkungan dalam desain pintu masuk dan pilar dinding. Muslim menguasai seni menggunakan lengkungan dalam konstruksi lebih dari budaya lainnya kelompok. Mereka mewarisi desain lengkungan sebelumnya dari Romawi dan Yunani dan menciptakan bentuk baru dari lengkungan seperti lengkungan tapal kuda dan lengkungan runcing. Gambar 2 menunjukkan penggunaannya baik sebagai elemen struktural dan dekoratif dalam bangunan mereka.

Kaligrafi Sebagai Pesan, Kaligrafi memainkan peran penting dalam Islam terutama karena penggunaannya dalam tulisan Al-Qur'an. Berdasarkan peran ini, itu dianggap sebagai salah satu elemen terpenting dalam seni muslim. Kaligrafi digunakan untuk membuat prasasti dangkal di dinding Muslim bangunan seperti istana, masjid dan rumah-rumah rumah tangga. Prasasti sering membawa pesan agama yang bersumber dari Al-Qur'an atau ajaran Muhammad. Implementasi dari kaligrafi dengan gaya seni geometris yang umum dengan dekorasi Islam. Simbol sering tertulis di bagian utama bangunan apakah itu terlihat oleh banyak orang. Pengulangan sering digunakan untuk menghasilkan pola di dinding. 


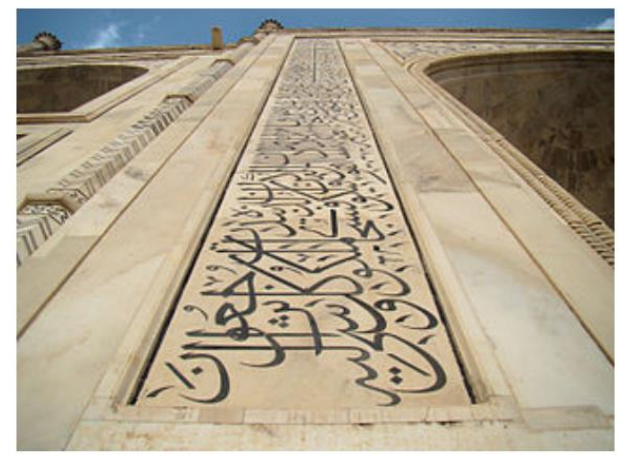

Gambar 3. Pesan yang disampaikan dalam Kaligrafi Arsitektur Islam (Sumber: (Ghasemzadeh, 2013))

Perulangan bentuk Geometri Sebagai Pesan, Dalam (Vernoit, 2000). Elemen arsitektur lain dalam arsitektur Islam adalah penggunaan geometris pola. Pola yang diterapkan dalam arsitektur Islam sangat bervariasi dalam kompleksitasnya. Hal ini terlihat dari desain yang sangat sederhana hingga yang sangat canggih sesaui dengan fungsi dan keindahan bangunan tersebut. Mode dekorasi ini juga sangat bergantung pada seni pengulangan, seni bentuk simetri, bentukan acak, dinamis dan terstruktur yang pada akhirnya akan menghasilkan sebuah pola-pola geometri yang mengandung pesan didalamnya. Arsitek dengan terampil mengintegrasikan bentuk geometris untuk menghasilkan pola yang unik dan simbol yang digunakan pada bangunan Gambar 4. Pola geometris memfasilitasi konektivitas antara bagian yang berbeda dari sebuah bangunan. Mereka juga menambahkan nilai estetika untuk struktur. Geometri juga dipercaya sebagai sumber pola kaligrafi.

Islam menentang produksi karya seni dan desain arsitektur yang menggambarkan tokoh binatang atau manusia. Menurut Islam, semua makhluk hidup dengan kemampuan gerak jatuh dalam domain Tuhan dan tidak boleh direplikasi dalam bentuk apapun seperti seni (AKKACH, 2005). Namun, ada sejumlah karya seni figural di dunia Islam tetapi sebagian besar terbatas pada bangunan dan objek sekuler. Patung-patung itu yang dihiasi dengan figur bukanlah pemandangan yang umum dalam Islam. 


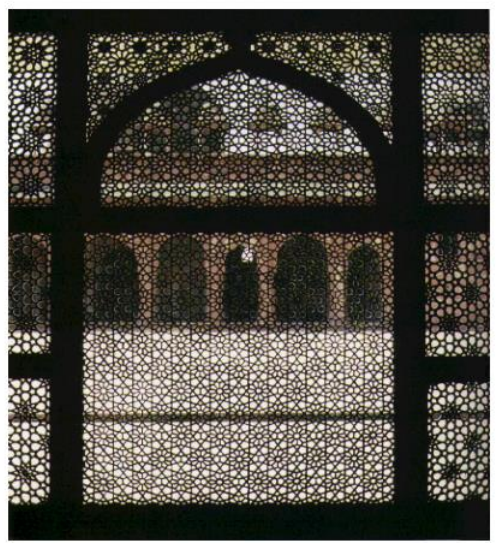

Gambar 4. Pesan yang disampaikan dalam Kaligrafi Arsitektur Islam (Sumber: GHASEMZADEH, 2013)

Arsitektur Islam adalah sebuah karya seni bangunan yang terpancar dari aspek fisik dan metafisik bangunan melalui konsep pemikiran islam yang bersumber dari Al-Qur'an, Sunnah Nabi, Keluarga Nabi, Sahabat, para Ulama maupun cendikiawan muslim. Aspek Fisik adalah sesuatu yang tampak secara jelas oleh panca indra. Dalam hal ini sebuah bangunan dengan fasade yang memiliki bentuk dan langgam budaya islam dan dapat dilihat secara jelas melalui beberapa budaya, seperti budaya arab, cordoba, persia sampai peninggalan wali songo. Bentuk fisik yang biasa diterapkan dalam sebuah bangunan sepetri penggunaan kubah, ornamen kaligrafi, dan sebagainya.

Aspek Metafisik adalah sesuatu yang tidak tampak panca indra tetapi dapat dirasakan hasilnya. Hal ini lebih kepada efek atau dampak dari hasil desain arsitektur islam tersebut, seperti bagaimana membuat penghuni/ pengguna bangunan lebih nyaman dan aman ketika berada di dalam bangunan sehingga menjadikan penghuni merasa bersyukur. Contoh lain hasil desain ruang ruang dalam pada hunian sebuah rumah tinggal. 


\section{HASIL DAN PEMBAHASAN \\ Ruang Dalam terkait Arsitektur Islam}
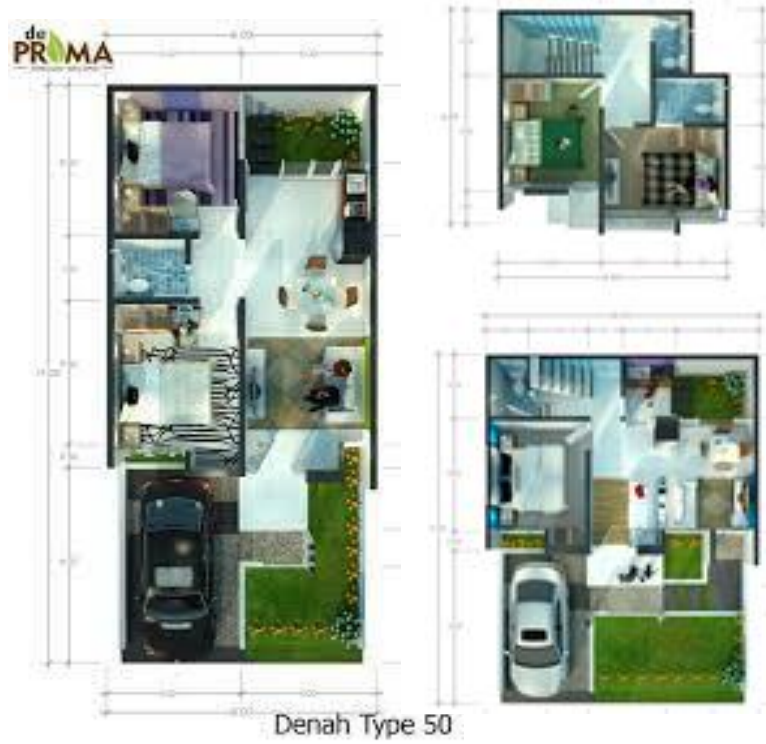

Gambar 5. Tata Ruang Pada De Primalnd Tunggulwulung, Malang

(Sumber: Analisa Pribadi)

Perwujudan ruang-ruang yang dirancang pada hunian di menekankan pada pendekatan tradisi tradisi atau aturan Islam dengan menyesuaikan keadaan masa sekarang dalam proses perancangannya, hal ini dapat dianalisa dari tata letak ruang yang memakai berbagai fungsi yang telah diadaptasi pada kebutuhan masa kini antara lain:

1. Teras sebagai zona penyambutan tamu

2. Ruang tamu, ruang tengah dan ruang kelurga dibuat terbukan dan menyatu dengan taman belakang sebgai implementasi desain arsitektur islam yang memaksimalkan bukaan untuk mendapatkan penghawaan dan pencahayaan alami.

3. Penempatan kloset yang berlawanan dengan arah kiblat.

4. Pemilihan material dan warna bangunan untuk elemen lantai, warna dinding disesuaikan dengan fungsi ruang didalamnya. 


\section{Dekoratif}

Pola bunga dan tanaman digunakan untuk mewakili alam. Seniman Muslim menggunakan bunga dan pohon untuk motif menghiasi pakaian, bangunan dan barang-barang lainnya. Hal ini terlihat dari berberap abngunan islam kuno yang ada pada Indonesia dan yang dibawa oleh Gujarat Arab misalnya, dimana berberapa gujarat Arab mengambil inspirasi dari desain bunga yang berasal dari Eropa dan Persia yang di terapkan pada pola kain dan pola benda benda seni.
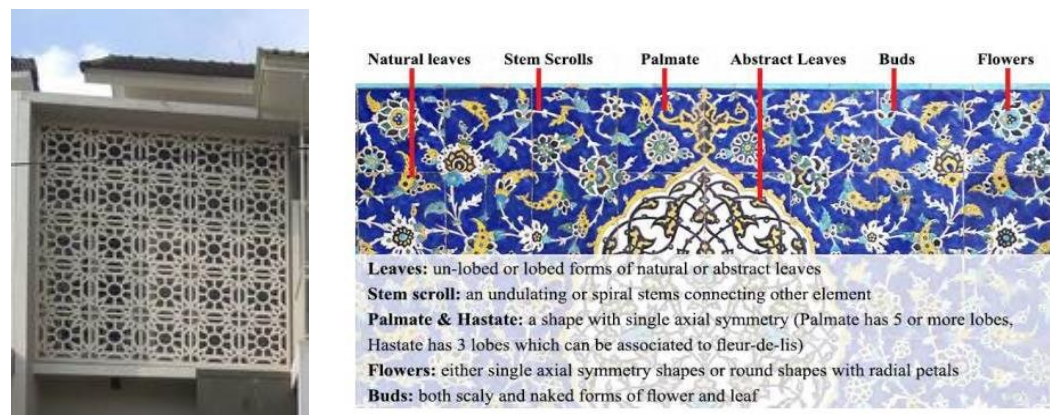

Gambar 5. Elemen Dekoratif Bunga Pada De Primalnd Tunggulwulung, Malang (Sumber: Analisa Pribadi)

Pada ornamen dan pola dekoratif yang diteapkan pada tipologi bentuk hunian di studi kasus De Primaland memiliki pola dekorasi yang diataptasi dari pola dekorasi Arsitektur Islam, Hal ini bisa diamati dari bentuk dasar GRC Kerawangan pada studi kasus yang dipilih menggunakan GRC Kerawangan dengan Motif Floral. Material GRC sendiri merupakan adalah ornamen dekoratif berupa sekat berlubang yang berfungsi sebagai ventilasi udara sekaligus pencahayaan alami.

\section{Lengkungan.}
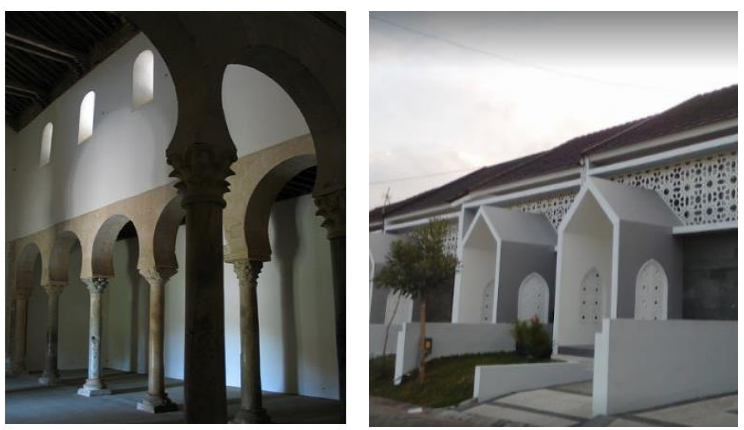

Gambar 6. Elemen Dekoratif Bunga Pada De Primalnd Tunggulwulung, Malang (Sumber: Analisa Pribadi)

PAWON: Jurnal Arsitektur, Nomor 01 Volume VI, Januari - Juni Tahun 2022, ISSN 2597-7636 
Sedangkan elemen lengkungan pada visual bentuk Arsitektur Islam adalah diwujudkan dengan adaptasi yang berbeda dengan bangunan sekitar yaitu dengan memodifikasi bentukan yang lebih runcing. Hal ini meruapakn salah satu bentuk adaptasi bentuk dengan olah bentuk berupa transformasi bentuk yang lebih adaptif. Malang memiliki curah hujan yang cukup tinggi sehingga bentukan runcing pada atap kanopi teras difungsikan untuk mengalirkan air hujan agar langsung turun ke tanah lebih mudah.

\section{Warna dan Kesan}

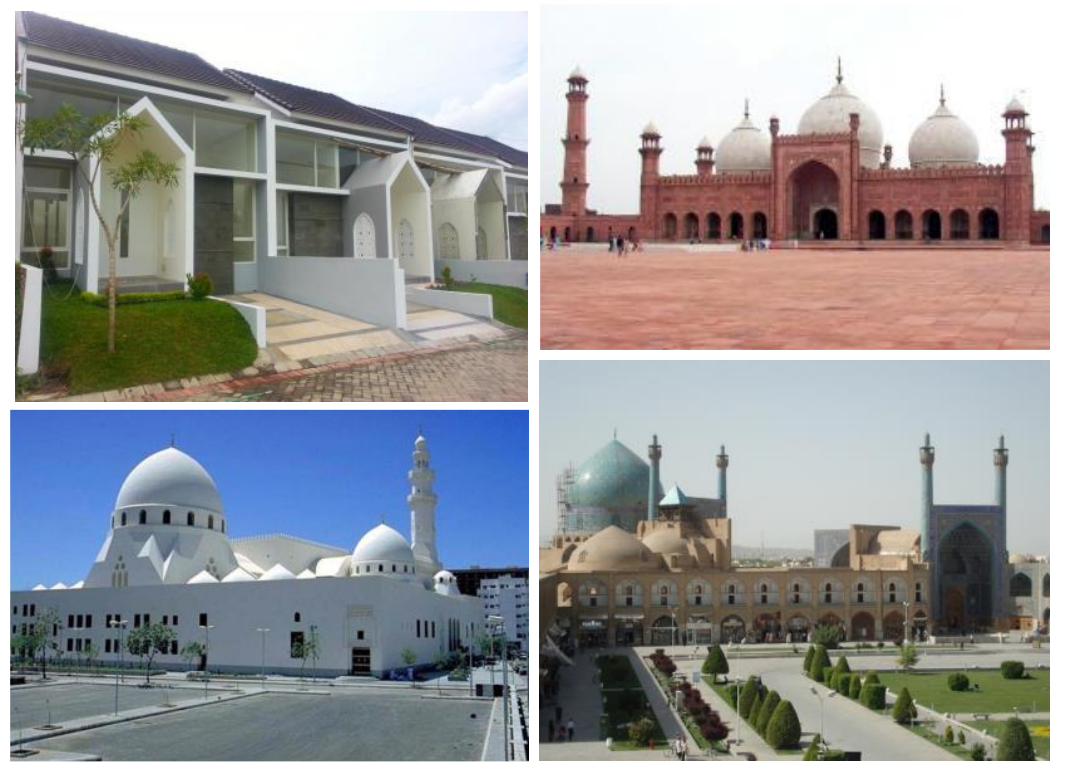

Gambar 7. Elemen Warna dan Kesan Pada De Primalnd Tunggulwulung, Malang (Sumber: Analisa Pribadi)

Warna yang dipilih adalah warna warna netral monokrom putih, abu-abu hal ini sama dengan prinsip Arsitektur Islam yang memilih warna warna natural seperti putih maupun merah tanah. Pemilihan warna alami ini terkait dengan ciri Arsitektur Islam yang terpengaruh oleh Seniman kontemporer Islam dimana para seniman islam termasuk arsitek yang dipengaruhi oleh budaya Islam menggunakan warna-warna natural yang identik cerah dan halus. Warna digunakan untuk menonjolkan obyek seni dan bangunan dam di iringi opleh kontras elemen desain arsitekturalnya, kontras bangunan juga diharapkan agar selaras dengan latar belakang lingkungan dimana seni bangunan itu di bangun. 


\section{Repitisi dalam Pola Geometrik}

\begin{tabular}{|l|c|c|}
\hline $\begin{array}{c}\text { 6-point } \\
\text { Geometrical pattern }\end{array}$ & $\begin{array}{c}\text { 8-point } \\
\text { Geometrical pattern }\end{array}$ \\
\hline Geometrical pattern
\end{tabular}

Gambar 8. Elemen Dekoratif Bunga Pada De Primalnd Tunggulwulung, Malang (Sumber: Analisa Pribadi)
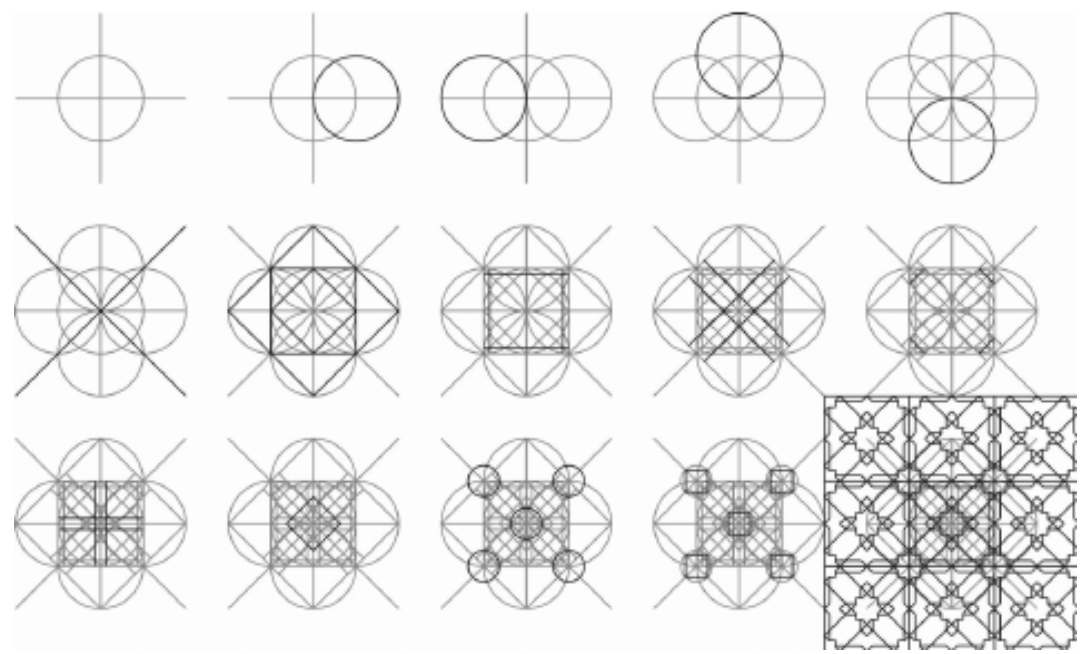

Gambar9. Elemen Dekoratif Bunga Pada De Primalnd Tunggulwulung, Malang (Sumber: Analisa Pribadi)

PAWON: Jurnal Arsitektur, Nomor 01 Volume VI, Januari - Juni Tahun 2022, ISSN 2597-7636 
Dalam Arsitektur islam mengenal empat bentuk dasar dari mana pola yang lebih rumit adalah: lingkaran, bujur sangkar atau poligon empat sisi, pola bintang yang sedikit komleks. Pola bintang berasal dari bujur sangkar dan segitiga yang tertulis dalam lingkaran yang tersusun terulang sedemikan rupa. dan poligon bersisi banyak sebagai salah satu bentuk paling kompleks. Meskipun bentuk dasar dan pola dalam Arsitektur Islam cukup rumit, hal ini sering kali disederhankan kedalam bentuk yang lebih sederhana. Kerumitan bentuk pola tersebut sebenarnya juga terpengaruh pada antara orang-orang Yunani, Romawi, dan Sasania di Iran, namun pola ornamen geometris ini mencapai puncaknya di dunia Islam.

Pola dan Desain geometris dalam seni Islam yang lebih sederhana sering didesain dengan dasar kombinasi kotak dan lingkaran secara berulang. Desain berpola ini memungkinkan saling tumpang tindih dan saling terkait satu sama lain, pola seperti ini sering disebut arabesque (pola yang sering digabungkan). Pola pola tersebut tergabung hingga membentuk pola yang rumit dan kompleks namun tetap harmoni. Dalam (Fikriarini, 2010), Pola pola tersebut merupakan keseluruhan dekorasi yang sering menjadi syarat dan ciri bangunan berarsitektur islam. Dalam seni Islam, pola geometris digabungkan, terjalin, dan diatur dalam kombinasi yang rumit, sehingga menjadi salah satu fitur yang paling membedakan antara bangunan Arsitektur Islam dengan bangunan arsitektur yang lain. Baik Arsitek maupun seniman Islam mengambil elemen-elemen kunci dari tradisi klasik yang berlandaskan spritual dan kearifan, kemudian mengelaborasi keduanya sehingga menghasilkan suatu bentuk dekorasi yang menekankan pentingnya kesatuan dan keteraturan. Pola kompleks yang ditemukan tersebut di sebut pola geometrik Arsitektur Islam.

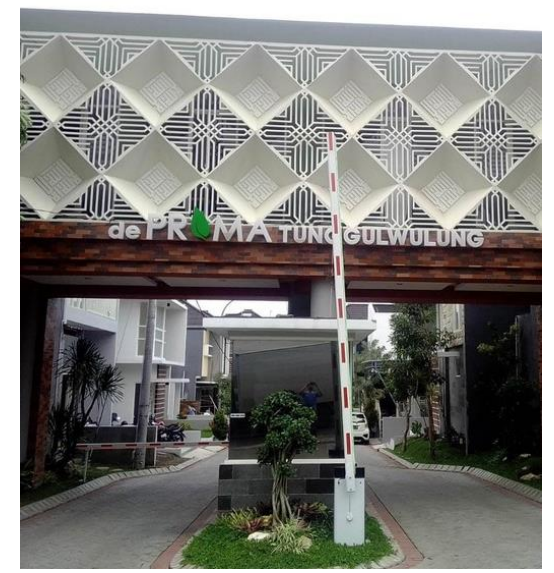

Gambar 10. Elemen Dekoratif Bunga Pada De Primalnd Tunggulwulung, Malang (Sumber: Analisa Pribadi)

PAWON: Jurnal Arsitektur, Nomor 01 Volume VI, Januari - Juni Tahun 2022, ISSN 2597-7636 
Seperti dengan Halnya Arsitektur Islam secara umum, Baik bagian dari bentuk Hunian hingga bentuk Gerbang Komplek hunian di de Primaland Tungguwulung mengadaptasi konsep hunian islam dalam bentuk nya, hal ini terlihat dari adaptasi gerbang yang didominasi oleh bentuk geometri dasar yaitu persegi dan bentuk geometri yang di ulang ulang secara repetitif hingga membentuk pola yang lebih kompleks (Gambar 10).

\section{KESIMPULAN}

Secara umum cluster de Primaland Tunggulwulung yang mengusung konsep hunian islam telah memenuhi Tipologi bangunan hunian yang berkonsep islam secara fisik, namun secara spasial dan fungsi ruang belum dapat digolongkan kedalam arsitektur islam.

\begin{tabular}{|c|c|c|c|}
\hline \multicolumn{4}{|c|}{ Analisa Mikro (Hunian) } \\
\hline \multicolumn{2}{|c|}{$\begin{array}{l}\text { Tipologi Berdasar Spasial } \\
\text { Arsitektur Islam }\end{array}$} & \multicolumn{2}{|c|}{$\begin{array}{c}\text { Tipologi Berdasar Elemen } \\
\text { Arsitektur Islam }\end{array}$} \\
\hline Bukaan penghawaan & $\mathbf{v}$ & Warna & $\mathbf{v}$ \\
\hline Courtyard & $\mathbf{x}$ & Kaligrafi & $\mathbf{x}$ \\
\hline Teras & $\mathbf{v}$ & Repetisi Pola Geometrik & $\mathbf{v}$ \\
\hline Fungsi Ibadah & $\mathbf{x}$ & Dekoratif & $\mathbf{v}$ \\
\hline Pengelompokan Zona Suci & $\mathbf{x}$ & Lengkungan (Arch) & $\mathbf{v}$ \\
\hline
\end{tabular}




\section{DAFTAR PUSTAKA}

Arnold, T. W. (1931). Legacy of Islam. london: ir.lucknowdigitallibrary.com.

Fikriarini, A. (2010). ARSITEKTUR ISLAM: Seni Ruang dalam Peradaban Islam. elHarakah. Vol.12 No.3, 194-205.

Ghasemzadeh, B. (2013). SYMBOLS AND SIGNS IN ISLAMIC ARCHITECTURE. Revista Europeia de Estudos Artisticos.

Hattstein, M. d. (20013). Islam Art and Architecture. Konemann:. Berlin: H.F.Ullmann Publishing Gmbh.

Vernoit, S. (2000). Discovering Islamic Art: Scholars, Collectors and Collections, 1850-1950. London: I.B. Tauris. 